\title{
LXXV. Final letter from Mr. William Jones on Dr. Wollaston's periscopic spectacle glass
}

\section{Wm. Jones}

To cite this article: Wm. Jones (1813) LXXV. Final letter from Mr. William Jones on Dr. Wollaston's periscopic spectacle glass, Philosophical Magazine Series 1, 42:188, 464-465, DOI: $10.1080 / 14786441308638365$

To link to this article: http://dx.doi.org/10.1080/14786441308638365

册 Published online: 27 Jul 2009.

Submit your article to this journal

Џ Article views: 2

Q View related articles $₫$ 


\section{[ 464$]$ \\ LXXV. Final Letter from Mr. WitliaM Jones on Dr. Wollaston's Periscopic Spectacle Glass.}

To Mr. Tilloch.

Sir,- I your Journal of last month, I observe that Dr. Wollaston bas continued his effort to impress the minds of your readers with a belief of his discovery of a new and improved form of the spectacle glass, and with an intimation that the eminent writers I quoted, as well as myself, did not rightly understand our old acquaintance the Meniscus, a lens drawn from oblivion under his new appellation of Periscopic. This merits no reply from me. It certainly would be more than "superfluous" for him to make any answer to my former palpable refutation and exposure ; and really, in commiseration for his unfortunate cause, his "silence" must be more agreeable to me than his contumacy.

My dissatisfaction with bim was not as an intruder merely presuming to recommend, but for first in a groundless manner depreciating the double convex or best form of lens, advertising the old meniscus form as containing a newly discovered optical principle, and then by the name of a patent exacting a payment for a glass triple the price of the common superior or more-perfect kind. In respect to the authority of a Mons. Biot's advertisement in a French newspaper, which Dr. W. has imported and translated as a certificate to gratify the "best acquainted with the merits of the question;" 'm my opinion, instead of supporting his case, it both disgraces and injures it.

Mons. Biot, no doubt, is a reputable astronomer, and an able mathematician; but as a skilful practical optician I cannot give him equal credit. He ingenuously states that he proposed a trial of the glasses convex without and concave within to his friend Mons. Cauchoix, and requested his opinion on the subject. The boasted and surprising effects of a pair of these spectacles are afterwards stated; and Mons. Biot, as a faithful friend to Dr. W., declares be will never wear any others : but there afterwards pops out an " inconvenience" of an appearance of " a variety of reftected images beside the principal olject viewed, which occasioned sume confusion."

Mons. Cauchoix, however, happily hit upon an expedient to remove this inconvenience, by diminishing the destructive concavity of the inner surface; or, in other words, to go caniously back towards the double convex form he had vitiated.-So did Mr. Dollond's workmen : but unhappily more; for, without waitine for a hit, and regardless of poss- 
tive and negative attributes, they snatched up a plane tool and with barbarous whirls annihilated periscopic. Mon, Cauchoix must not do so; for he no doubt expects to get some money by the lanettes a la bombere, as well as Dr. W. for his a la periscopique.

As I prefer amity to a difference with a French philosopher, I shall dispense with adverting to what I know to be M. Biot's errors and illusion. He must allow me one remark, that is, that his countrymen should witness a perfectly fair experiment of a comparison between the double convex and his adopted meniscus form of glasses, for meniscus, periscopic, and bombée, are synonymous terms.

There will also be expected from him a mathematical of geometrical demonstration of the superiority of the form he bas pledged himself to; for Dr. W, on his part has not been able to produce any mathematical demonstration whatever. But how is it that Dr. W. for these seven years past has not called to his aid some competent profescor or tutor from the university in which he has studied to be his champion of interest? he surely knows that there are several both at Cambridge and Oxford, quite able to decide upon our trivial scientific question. Is there no one among his mathematical friends (and constant attendants at the bonourable Society to which he is Secretary) willing to be an English evidence of his discovery and a witness to the surprising field of view gained by the meniscus? Is it by a foreigner unly that the interest of his cause is to be espoused maintained and propagated? In my defence of the double convex lens, I possess an indubitable authority among others of a declaration by that late excellent optician Dr. Maskeline, that Dr. W's form of lens of the meniscus kind.is the worst of all others for any optical purpose what. soever!

I could adduce something still stronger and more conclusive; but, really, sir, I am asha.ned to trespass any further on the patience of your readers, and take up more pages of your valuable Journal. Enough is already before the public, to produce by an easy experiment a full conyiction of the truth. I continue,

$$
\begin{gathered}
\text { Sir, } \\
\text { Your respectful and obedient servant, } \\
\text { Holborn, Dee. 15, 1813. } \\
\text { WM. Jones. }
\end{gathered}
$$

Vol, 42. No. 188. Dec. 1813. Gg LXXVI. Re* 